\title{
„NU E CAZUL SĂ NE DĂM CEEA CE NU SUNTEM"1. SPRE O ÎNŢELEGERE A COMUNISMULUI PRIN BANDIT⿱II DE VASILE ERNU
}

\section{“IT'S NOT THE CASE TO PRETEND TO BE SOMETHING WE ARE NOT". TOWARDS AN UNDERSTANDING OF COMMUNISM THROUGH THE BANDITS BY VASILE ERNU}

\author{
Iulia STOICHIȚ \\ Universitatea „Transilvania” din Brașov/ "Transilvania” University of Brașov \\ e-mail: iuliastoi@yahoo.com
}

\begin{abstract}
The Bandits", Vasile Ernu's second volume of his trilogy, the trilogy of marginal men, describes the world of thiefs, of bandits, of criminality in a communist society, without the narrator ever becoming one of them. He is more of an adopted son, someone who has almost unmediated access to this world without suffering the repercusions of revealing that world's secrets. This should not to be understood that he has total access to the bandits' secrets, but that he is not viewed as a threat, even if he reveals more of this world than others. The narrator is accepted because he does his best to be himself and this is a value of utmost importance for this marginal group of people, others knowing and owning their identity, the type of narrative they tell about themselves. On the other hand, the narrator is himself a marginal man as well, considering the fact that he grew up among religious people who were quite fundamentalists in their way of expressing this belief (but not in the way in which we picture today religious fundamentalism: bombing, Muslims, terror). Thus, this essay is meant as a study of one's sense of identity when having to juggle with more identities, when having to evade (or even be subversive towards) the more pervasive, totalitarian regime in which these marginal men find themselves.
\end{abstract}

Keywords: marginality; communism; identity; ambivalence; Vasile Ernu.

\section{Introducere}

Vasile Ernu, de origine basarabeană, a adoptat și a fost adoptat de cultura română, unde s-a dovedit până acum un scriitor prolific ${ }^{2}$, dar și greu

\footnotetext{
${ }^{1}$ Un citat din Bandiţii, Vasile Ernu, cu desene de Laurenţiu Midvichi, Polirom, Iaşi, 2016.

2 A publicat treisprezece cărți, prima fiind Născut în URSS, apărută în 2006, dar și trei volume colective coordonate în colaborare cu alți autori.
} 
încadrabil. Un termen care pare totuși să predomine în legătură cu scrierile sale, cel puțin în interviurile pe care le-a oferit, este docu-ficțiune ${ }^{3}$ : ideile care îl interesează pe Ernu au nevoie și de o poveste, nu sunt de ajuns textul teoretic, documentul, cercetarea ${ }^{4}$.

Deși este un om de stânga declarat, această afiliere politică trebuie contextualizată și nuanțată. Într-un interviu din 2020, Bogdan Coșa îl întreabă pe Vasile Ernu despre bazele platformei CriticAtac, dacă aceasta poate fi considerată un ,îndreptar” pentru neoliberali și conservatori. Răspunsul autorului este următorul:

„M-ai prins. Multe din atitudinile mele «de stânga» asumate, uneori percepute ca «radicale», au un filon mai degrabă religios decît «marxist» sau mai știu eu ce curent de stânga. Chiar dacă nu-mi sunt străine teoriile occidentale dinspre stânga. [...] Comunitatea din care provin, chiar dacă e una profund conservatoare, are o practică exemplară mai degrabă socialistă: fără ierarhii, decizii colective prin vot egal, într-ajutorare, redistribuție după nevoi și necesități, lupta împotriva acumulării văzută ca un rău, egalitarism, bani comuni etc. Dar asta am înțeles mult mai tîrziu.” (Ernu, 2020).

Viziunea sa de stânga este motivată, în primul rând, de o practică susținută în perioada copilăriei, când a trăit într-o comunitate de sectanți, și abia în al doilea rând, de limbajul specific orientărilor ideologice de stânga, nu invers, cum se întâmplă de cele mai multe ori cu intelectualii de stânga. Acest aspect este important în ideea în care în Bandiții, volumul avut în vedere, din punctul meu de vedere, nu primează ideologia, politicul, deși are o dimensiune ideologică evidentă, prin constanta înfruntare dintre bandiți ${ }^{5}$ și putere (regimul comunist), ci este mai degrabă o continuare a drumului formativ început de narator în Sectanții ${ }^{6}$ și continuat în acest volum. În cazul de față, prezența poveștii și a personajelor permite o nuanțare a problematicii marginalității sociale, care se construiește în raport cu un centru, fie el

\footnotetext{
${ }^{3}$ „Eu fac un soi de docu-fiction: o proză documentară. Acolo sunt prezente idei destule, însă ele capătă viaţă şi forme, ele au deja o formă cotidiană specifică prozei care are eroi şi poveste." (Ernu, 2020)

4 „In procesul scrierii, însă, lucrurile se transformă, se modifică şi chiar capătă forme neaşteptate, conflictuale şi uneori în dezacord cu ce ai gândit tu. Adică ideile transpuse în poveşti sunt cu totul altceva decât în teorie sau idei «lipsite de carne». De aceea eu rămân descumpănit când cărţile mele sunt trecute la zona «teorie». Eu nu fac teorie, istorie a ideilor, antropologie sau altele din această zonă.” (Ernu, 2020)

5 „Nume dat de putere și de oamenii de rând celor care încalcă sistematic legea. De obicei, bandiții își spun hoți. Câteodată folosesc și termenul «bandit», dar fără conotația negativă atribuită de «putere», ci doar ca o modalitate de autoidentificare" (Ernu, 2016: 7)

${ }^{6} \mathrm{Cu}$ toate că și primul volum ar merita atenție în egală măsură, analiza acestuia rămâne o temă pentru un alt eseu.
} 
ideologic sau sub forma unui imaginar social dominant într-un anumit moment dat. Astfel, marginalitatea devine o problemă de perspectivă, de contextualizare, de alegere a grupurilor analizate, de cum se raportează individul la apartenența sa la un grup (sau mai multe), cum se definește un grup, cum își negociază grupurile pozițiile în societate, iar aceste probleme nu pot fi niciodată tranșate satisfăcător doar prin dihotomia „dreapta-stânga”. Ceea ce primează sunt umanitatea personajelor și drumul formativ parcurs de narator:

„Impresionantă este, la Vasile Ernu, afecțiunea profundă, vibrantă, față de lumea pe care o descrie. Dincolo de orice retorică a «datoriilor uitate» și a «reprezentării sărăciei», perspectiva sa asupra semenilor este una profund umană. Indiferent de încheierile politicoideologice pe care le trage din ea, frământarea lui pentru «cei mulți şi umili» (deși «bandiții» sunt departe de a putea fi considerați umili...) nu este una ideologică, artificială, ci derivă din experiența directă cu ființe reale care se mișcă într-o lume reală.” (Dobrescu, 2017).

Din motivele ilustrate mai sus, dar şi altele, care țin de spațiu și interesele mele punctuale în legătură cu acest eseu, nu voi insista asupra implicațiilor politic-ideologice ale volumului, pe care autorul le suprapune peste umanitatea din volum, ci preponderent asupra felului în care Bandiții devine un fel de Bildungsroman ${ }^{7}$ pentru naratorul volumului, Vasile Andreevici. Din punct de vedere identitar, naratorul are o experiență concretă, localizabilă, care declanșează primele întrebări identitare, locul său în lume, dar și al altor indivizi sau grupuri. Prin contact constant cu diverse grupuri, fiecare având propriul său model pe care îl proiectează, identitatea naratorului începe să se destabilizeze pentru a se redefini, în cele din urmă. Dar această cristalizare a identității naratorului nu este un proces neapărat explicit, ci adeseori este prezentat ca fiind implicit, prin descrierea și cartografierea aproape antropologică a grupului de bandiți din fosta Uniune Sovietică. Încercând să descrie o lume, inaccesibilă în mare parte majorității (sau accesibilă doar superficial, prin prisma clișeelor de reprezentare pe care le propune discursul dominant), pe care nici naratorul nu o înțelege totdeauna, fie pentru că îi lipsesc informații, fie pentru că nu există deschidere, disponibilitate din partea sa, anumite părți ale identității sale sunt iluminate sau puse într-o perspectivă diferită. Astfel, în mod indirect, sunt arătate ipocriziile societății. Deși există locuri în care naratorul se

\footnotetext{
${ }^{7}$ Această etichetă este mai degrabă provizorie, ținând cont de faptul că nu mi-am propus să analizez în detaliu și identitatea pe filieră religioasă a naratorului, care motivează acțiunile sale, dar și locul său în cadrul societății. Este foarte posibil ca eticheta de Bildungsroman să fie invalidată sau să fie insuficientă, având în vedere identitățile disputate.
} 
intersectează cu credințele și modul de raportare la lume al bandiților, acesta nu ajunge niciodată să fie el însuşi unul, delimitându-se de activitatea lor principală, furtul. $\mathrm{Cu}$ toate acestea, deși se va dovedi că el s-a integrat social și economic în România, o lume complet diferită de cea din Basarabia, din punct de vedere afectiv, emoțional și psihologic, continuă să se simtă apropiat de spațiul în care s-a format, locul în care a cunoscut nemijlocit marginalitatea. Pentru analizarea marginalității atât de susţinută de naratorul din Bandiții, în cele ce urmează, o să expun teoria lui Dan Țăranu, care, pe lângă faptul că propune o teorie a marginalității tripartite, pleacă de la premisa că există un topos al marginalității în romanul românesc.

\section{Delimitare teoretică}

În teza sa de doctorat, Dan Țăranu (2013) aplică teoria unor romane apărute în perioada, asumat ca fiind aleasă relativ arbitrară, 1900-1945. Înainte de a trece efectiv la explicarea și testarea teoriei, o să preiau o definiție din volumul menționat, care să ajute la delimitarea „spațiului” avut în vedere când mă refer la marginalitate:

„[Este] marginal un grup social sau un individ «izolat de sau care nu se conformează societății sau culturii dominante; (perceput ca fiind) la granița societății sau a unei unități sociale; aparținând unui grup minoritar (implicând frecvent dezavantaje care decurg de aici)»" (Țăranu, 2013: 49).

Având în vedere că există un punct de plecare comun, în accepția autorului există trei tipuri de marginalitate: (1) marginalitate atribuită, (2) marginalitate autoatribuită și (3) marginalitate negociată sau bi-focală. Pentru a înțelege cum funcționează marginalitatea atribuită, este important să subliniez faptul că, în acest caz, cel mai mult contează cine atribuie o etichetă care ar putea marginaliza un individ sau un grup social. Accentul cade pe observator și, eventual, pe procesul în sine de atribuire. Cel etichetat aparține planului secund, în ideea în care acestuia i se refuză posibilitatea de a reacționa în orice fel la etichetare. In extremis, marginalitatea atribuită poate fi definită, parafrazând o frază celebră a lui Flaubert, ,centrul sunt eu”. Astfel, tot ce este în afara „mea” poate fi considerat margine/marginal:

„Dacă punctul de origine referențială este sinele, cel care vede și structurează, chiar şi când vorbim doar despre iluzia sinelui că face asta, putem înțelege de ce un adjectiv ca marginal nu are antonim. Acesta este, poate fi, un simptom că cel care face distribuția, cel care situează lucrurile sau persoanele atât în spațiu, cât și în funcție de interesele sale, nu este simultan prins într-un proces reflexiv, de autoconștientizare a propriei poziții. Este de la sine înțeles că cei care 
sunt marginali sunt astfel pentru că se află la limita percepției, intereselor sau valorilor mele, eu, cel care, inevitabil, stabilesc asta (sau cred că o fac sau sunt obligat să o fac, totul trece, cel puțin pronominal, prin mine).” (s.n., I.S.) (T,ăranu, 2013: 91-92).

Astfel, marginalitatea atribuită poate fi înțeleasă ca un proces de atribuire mai ales lingvistic, arbitrar sau nu, unde ,totul trece, cel puțin pronominal, prin mine" (Țăranu, 2013: 92). Tot ce îmi este străin mie, câmpului meu perceptual devine marginal. In plus, îi și refuz celui etichetat ca marginal calitatea de a fi subiect la rândul său. Cel căruia i se atribuie o etichetă nu numai că poate conștientiza atribuirea, dar ,poate intra în posesia ei”, adică poate să devină conștient de etichetă și să o internalizeze, transformând-o dintr-un dezavantaj într-un avantaj (cu rezerva că aceste cazuri sunt particulare):

„La această dimensiune atribuită a marginalității se adaugă și un element foarte important, şi anume marginalitatea autoatribuită. Analizată de Howard S. Becker în termeni de «autosegregare», ea presupune conștientizarea diferenței, transformarea ei în atu, afișarea însemnelor marginale ca apartenență la un grup distinct de corpul societății etc. (s.n., I.S.). Segregarea este, desigur, o valoare menită să creeze solidaritate în interiorul comunității artistice și are o dimensiune de regulă artificială, dar ea funcționează ca un principiu al identificării, creând astfel o nouă comunitate.” (Țăranu, 2013: 177).

După cum se poate vedea, un grup social care se înscrie în schema marginalității autoatribuite este cel al artiștilor. Dar acestui grup i se pot adăuga atât bufonul, cât și geniul neînțeles și victima. Aici ar putea fi adăugat și grupul bandiților, în ideea în care aceștia transformă în atu situația care li sa oferit. Până acum, cele două tipuri de marginalitate se dovedesc a fi rigide, în sensul în care ceea ce contează cel mai mult este poziția celui care atribuie sau își atribuie o etichetă. Această poziție fie este una dominatoare, fie este conotată ca atare, în cazul celui care isși atribuie o etichetă. Nici cel care atribuie, nici cel care își atribuie sieși o etichetă nu sunt văzuți, din punct de vedere identitar, ca fiind dinamici, capabili de a se chestiona sau a se adapta la diferite contexte sociale. Ceea ce poate schimba această dinamică rigidă din punct de vedere lingvistic (dar nu numai) este recunoașterea, din partea ambilor indivizi, a faptului că există amândoi ca subiecți, în proprii lor termeni, iar ei se pot întâlni într-un no man's land, unde poate avea loc un dialog real, în urma căruia, inevitabil, fiecare subiect își va reformula sau redefini poziția. Aceasta este și cea mai ideală situație/definiție cu putință pentru marginalitatea negociată/bi-focală, care se înscrie în logica lui ,și/și” sau ,nici/nici”: 
„Mai simplu spus, «Nu este suficient să-ți afirmi o identitate; această afirmare trebuie să fie, de asemenea, validată sau nu, de cei cu care avem de-a face. Identitatea nu este niciodată unilaterală». [...] Între identitatea pe care o proiectez în exterior și definițiile care o circumscriu din exterior există o permanentă negociere, o tranzacție de sensuri care presupune nu doar adaptabilitate, un «management al impresiilor», realizat prin diverse «prezentări ale sinelui», pentru a împrumuta formulele lui Erwin Goffman, ci și posibile tensiuni, neconcordanțe, variații și schimbări de perspectivă care au un efect direct asupra identității.” (s.n., I.S.) (Țăranu, 2013: 223)

După cum am încercat să arăt până acum, marginalitatea este un element important în definirea identității unui individ, mai ales o dată cu modernitatea. Plasarea (sau nu) la margine este cu atât mai importantă cu cât ea este mereu fluidă și depinde întotdeauna de privirea cuiva, fie a individului etichetat ca fiind marginal, fie de cea a celui care etichetează, pentru că, mai devreme sau mai târziu, aceste priviri se întâlnesc și se confruntă (productiv, din punct de vedere identitar, sau nu). Eticheta de marginal (dar nu numai) se vede pusă constant în situația de a fi reconfirmată, de a-și consolida poziția (sau de a o pierde). Iar marginalitatea nu ține cont doar de un singur aspect al identității cuiva.

Înainte de a trece direct la analiză, aș mai atrage atenția asupra unui aspect care se va dovedi important, deși va fi discutat doar pe jumătate, oricât de impropriu ar suna această formulare. In volumul său, Dan T,ăranu atrage atenția asupra faptului că există și „,culturi marginale”, termen adoptat de la sociologul Milton M. Goldberg. Raţionamentul este următorul:

\begin{abstract}
„Dacă individul marginal se naște într-un mediu care, din punct de vedere antropologic, este situat într-o poziție biculturală intermediară, împărtășind această condiție marginală obiectivă cu alți indivizi, iar această condiție reprezintă experiența sa culturală primară, acest individ este, de fapt, integrat, adaptat într-o cultură marginală." (T,ăranu, 2013: 275).
\end{abstract}

Cum am menționat deja, Vasile provine dintr-un grup prin excelență marginal, cel al sectanţilor. Această identitate, în mod evident, este explorată mult mai în profunzime în volumul Sectanții, dar cu toate acestea, până în momentul în care naratorul face cunoștință cu banditul supranumit „Profesorul”, la care se adaugă și o experiență formatoare importantă, care îl va arunca din lumea copilăriei în cea a adolescenței (ambele experiențe vor fi analizate în detaliu mai jos), se poate afirma despre narator că este adaptat 
unei culturi marginale, cu atât mai mult cu cât sunt îndeplinite trei precondiții necesare:

„existența unui mediu familiar, securitatea pe care acesta o asigură individului și, mai ales, insistă autorul [Milton Goldberg - n.m. I.S.], faptul că frustrarea de a se confrunta cu contrastul dintre propriul cod cultural și definițiile celorlalți $[. .$.$] este diminuată pe cât posibil."$ (Țăranu, 2013: 276).

Abia în Bandiții naratorul începe procesul de maturizare, și ajunge să conteste o parte din valorile cu care a crescut, prin expunerea la alte grupuri sau (sub)culturi. Și dacă aceste argumente nu sunt de ajuns pentru încadrarea naratorului într-o cultură marginală, mai propun un argument, subliniat atât de Milton Goldberg, cât și Dan Țăranu: o cultură este considerată marginală dacă aceasta are o tradiție întreagă în spate prin care ea își gestionează marginalitatea, caracteristică bifată și de grupul din care provine Vasile (naratorul), chiar dacă rămâne să demonstrez acest lucru într-un eseu viitor. Firesc, în prezentul eseu mă interesează momentul în care cultura marginală din care provine naratorul ajunge să nu îi mai fie suficientă din punct de vedere identitar, momentul în care încep explorările și întrebările, chiar dacă aceste explorări nu sunt tot timpul vizibile sau explicite de-a lungul volumului.

\section{Banditul: corpul străin al societăţii comuniste care se (auto)izolează prin vizibilitate}

Profesorul este, poate, cel mai important personaj, pe lângă naratorul în sine, pentru ceea ce ajunge să reprezinte pentru Vasea, dar și pentru faptul că devine simbolul trecerii de la copilărie la adolescență. Iar Profesorul devine vizibil pentru narator instantaneu din momentul în care îl cunoaște:

„În fața mea se afla un domn ceva mai în vârstă decât tata, cam slăbănog, dar cu genul acela de fibră întinsă bine pe oase. Tipul care nu pune un gram de grăsime pe el. Doar os și fibră. [...] O piele arsă de soare, puțin îmbătrânită, dar încă bine întinsă pe corp. [...] E culoarea pe care o capeți când stai la soare din primele zile ale primăverii până în ultimele zile ale toamnei târzii. [...] Care se formează în timp și după băi de soare îndelungate. [...] Însă ce m-a uimit cel mai mult erau desenele de pe corpul lui. [...] Când s-a ridicat din pat, am văzut acele picturi despre care aveam să aflu mai târziu că se numesc tatuaje și că fiecare are rostul lui. Mai ales pentru cine le purta." (Ernu, 2016: 29-30). 
Primul lucru cu care ia contact naratorul când îl cunoaște pe Profesor este corpul său, foarte diferit de alte corpuri. Vasea este cu atât mai impresionat (și impresionabil) cu cât încă nu a început procesul de maturizare propriu-zis, iar clarificările cerute ulterior, în urma altor ocazii de vizitare a Profesorului, rămân fără un răspuns direct din partea tatălui său. Și nu este impresionat doar de corpul banditului, deși acesta este primul strat cu care intră în contact, ci și prin ceea ce acesta vorbește cu tatăl său:

„Îngerii răi care vă pot lua totul. Îngerii negri care vă pot transforma viața paradiziacă în coșmar. [...] Noi suntem lăsați de la Dumnezeu să facem această dreptate pentru că voi ați construit o lume atât de nedreaptă, iar noi suntem singurii care vă aduc aminte de asta cu regularitate. Noi suntem visul vostru urât, noi suntem întruchiparea minciunii voastre. [...] Mi se păreau atât de stranii toate aceste cuvinte, fraze, cu toate că Profesorul vorbea ca un pastor din «secta» mea. Lucrurile îmi sunau cumva familiar, dar parcă întoarse pe dos, parcă totul avea un înțeles răsturnat.” (Ernu, 2016: 46).

Această oglindă negativă a lumii celor majoritari, pe care o reprezintă bandiții, este, de altfel, unul din firele roșii ale volumului. Iar pentru acest lucru, bandiții par să exercite o forță de atracție irezistibilă asupra naratorului, fapt explicabil prin diferența de vârstă dintre Vasea și Profesor la momentul când se cunosc prima dată. Pe de altă parte, această fascinație atribuită copilului, deși legitimă (și de înțeles, chiar recomandată din punct de vedere naratologic, dacă ar fi vorba de un roman în adevăratul sens al cuvântului, dar aceste etichetări sunt aruncate în aer de autorul însuși, care are grijă ca volumul să nu fie încadrabil într-o categorie clară), pe parcursul volumului, pe măsură ce naratorul se maturizează și îmbătrânește, identificarea, afilierea nu mai este complet inocentă, sau mai bine spus, neafiliată ideologic.

Revenind la Vasea (copilul) și la fascinaţia sa pentru corpul Profesorului, există o întreagă istorie în ceea ce privește arta tatuării, care e posibil să fie la fel de veche ca primele semne de civilizație (sau poate chiar mai veche). $\mathrm{Cu}$ toate acestea, istoria tatuajului printre criminalii din fosta Uniune Sovietică este diferită, și, într-o anumită măsură, face parte din istoria politică a U.R.S.S.-ului. Pe scurt, fiecare tatuaj are semnificația sa, care variază în funcție de model: de la a arăta gradul și reputația unui criminal în cadrul „organizației”, , câte pedepse a ispășit în închisoare sau alte însemne

\footnotetext{
${ }^{8}$ Vasile Ernu oferă la începutul volumului său un scurt dicționar de termeni folosiți în lumea bandiților, care să faciliteze înțelegerea. De asemenea, în capitolul Legea hoților şi povestea castelor spusă de ultimul hoț în lege (vezi cu precădere pp. 208-212), autorul arată cum lumea criminală funcţionează după un sistem asemănător castelor din India, nerespectarea statutului castei atrăgând sancţiuni pe măsură din partea celor îndreptăţiţi să le aplice, adică „hoții în lege” (sau elita lumii infracționale).
} 
identitare ale vieții de bandit, menite a fi decodificate tot de alți bandiți, în niciun caz de un „fraier"9. Important aici este modul în care tatuajul devine un simbol al identității acestor bandiți. Plecând de la premisa că în societatea comunistă, orice comportament menit să individualizeze pe cineva, fie el cât de mic sau nesemnificativ, atrage atenția din partea puterii asupra acelui individ (și nimeni nu își dorește să devină vizibil pentru regimul comunist), a purta cu tine, la propriu, tot timpul cu tine ceea ce ești, din punct de vedere identitar, echivalează (aproape) cu o declarație politică adresată sistemului. Din perspectiva regimului, înseamnă că purtătorii tatuajelor se comportă ca niște corpuri străine înăuntrul regimului totalitar, la fel cum pigmenții folosiți în tatuare sunt un corp străin pentru organism, care este izolat la propriu de sistemul imunitar ${ }^{10}$. Pe de o parte, acești bandiți sunt izolați, într-o oarecare măsură, de restul corpului societății prin intermediul închisorilor (atunci când sunt sau se lasă prinși), pe de altă parte, într-un fel, nici nu mai este nevoie de închisori în ceea ce îi privește, din moment ce sunt atât de vizibili și individualizați prin tatuaje. Dacă regimul comunist alege închisoarea pentru însemnarea lor, neînțelegând că acest lucru le oferă prestigiu acestor indivizi (cel puțin, înăuntrul grupului lor), bandiții înșiși aleg mai degrabă metoda biblică: „semnul” lui Cain (adică tatuajul), pentru ca Ceilalți să știe cine este de evitat, dar și ce relații au cu puterea, la fel cum Cain a avut cu Dumnezeu din momentul în care și-a ucis fratele Abel. Prin această asociere indirectă, naratorul adult revine în punctul din care a plecat inițial, grupul său de sectanți, care vor să salveze lumea, doar că se întoarce schimbat, cu un discurs întors pe dos, negativ, la fel ca Profesorul. Până la finalul volumului, nu mai salvează nimeni și nimic lumea deoarece Cain a câștigat, prin alianța sa cu Dumnezeu, chiar dacă Acesta încearcă să o ascundă ulterior. Puterea bandiților vine din faptul că, știind ce urmează, decid singuri termenii propriei lor izolări de corpul societății care nu îi poate elimina complet,

\footnotetext{
${ }^{9}$ Cei care nu aparţin lumii bandiţilor, conform argoului propriu.

10 Samuel Steward, un fost profesor universitar din Statele Unite, care a fost parte a sistemului timp de douăzeci de ani, în anii 1950 renunţă la profesia sa (gest care, evident, îl plasează într-o zonă de marginalitate faţă de mediul academic) şi devine un artist tatuator. În unul din capitolele cărţii sale - care a rezultat în urma anilor întregi de „,cercetare în teren”, practicând această meserie - acesta explică de ce nu dispare pigmentul introdus în piele: „Majoritatea [artiştilor tatuatori - I. S.] nici nu ştie exact de ce pigmentul în sine nu este absorbit sau digerat de piele. Răspunsul la asta este simplu: pigmenţii sunt chimicale metalice inerte; pielea încearcă să îi elimine ca substanţă străină în timpul procesului de vindecare. Cum asta eşuează, sub pigmenţi se formează un strat chistic subţire, [organismul] renunţă şi îi lasă în pace.” (Steward, 1990: 81). Această traducere, ca şi cele ce vor urma, îmi aparțin. În original: "Neither do most [tattoo artists - I. S.] know exactly why the pigment itself is not absorbed or digested by the skin. The answer to that is simple: the pigments are inert metallic chemicals; the skin tries to eject them as a foreign substance during the healing process. That failing, it grows a thin cyst layer beneath the pigments, and then gives up and leaves them alone."
} 
pentru că ar atrage cu sine un dezechilibru și mai mare. Rolul lor este să exploateze slăbiciunile ce apar în sistem din modul în care este construit el în sine.

Astfel, toate celelalte însemne vizuale ale Profesorului - cămașa înnodată la bază, pielea prea bronzată, corpul atletic - devin simboluri ale recuzitei identitare a banditului. Faptul că, ulterior, naratorul încearcă să imite comportamentul vestimentar al Profesorului (purtarea cămășii la fel ca el), atrage următoarele consecințe: (1) un adult recunoaște că a avut loc încălcarea unei reguli nescrise; (2) are loc admonestarea și reinstituirea ordinii de dinainte de această transgresiune ${ }^{11}$, prin interdicție și prin oferirea lecției corespunzătoare; (3) conștientizarea (tardivă) a transgresiunii ${ }^{12}$ de către narator, care va înțelege mult mai târziu importanța felului în care acesta se prezintă pe sine în lume și de ce atât tatăl său, cât și Profesorul, în discursul său, insistă asupra asumării identităţii.

\section{Lumi și identităţi în confruntare sau „Sfârșitul copilăriei”"13}

Momentul în care Vasea ajunge să-l caute pe Profesor unde îi spusese că-1 va găsi dacă va vrea vreodată să-1 vadă: localul „Ancora neagră” devine un punct de referință din punct de vedere identitar. Naratorul o întreabă pe casierița localului de Profesor, așa cum acesta din urmă îl instruise când se cunoscuseră prima dată. Ea rămâne uimită și îl întreabă: „Tu cine ești?”, întrebare care își va elucida sensul mai târziu. Când este pomenit numele celui care i-a adus cămașa Profesorului, Maki, situația se complică. Casiera cheamă prin gesticulația mâinilor un bandit, să se ocupe de intrus. Lucrurile între cei doi escaladează, iar în cele din urmă, băiatul se trezește cu un pumn din partea banditului Keșa, care îi sparge nasul. Apar Profesorul și Maki, iar situația se rezolvă: naratorul este luat din local și dus într-un birou, să i se

${ }^{11}$ Conceptul de „transgresiune” a fost făcut cunoscut cel mai bine de Peter Stallybrass și Allon White în The Politics and Poetics of Transgression/ Politicile și poeticile transgresiunii (1986), unde cei doi autori pornesc de la analiza unei alte lucrări importante, Rabelais și lumea sa, de Mihail Bahtin, care are în centru categoria carnavalescului. Totuși, pentru a simplifica discuția, când mă refer la termenul de „transgresiune”, am în minte următoarea definiție: „Trangresiunea ... este acel comportament care încalcă regulile sau depășește barierele.” (Jenks, 2003: 3) În original: „Transgression ... is that conduct which breaks rules or exceeds boundaries."

12 În nota precedentă, în mod intenționat nu am menționat și faptul, important, de altfel, că „transgresiunile sunt în mod vădit specifice situației și variază considerabil peste spații sociale și prin timp.” (Jenks, 2003: 2-3), adică sunt dependente de contextul în care ele au loc. În original: „transgressions are manifestly situation-specific and vary considerably across social space and through time." În acest context, un gest aparent banal, ca purtarea cămășii înnodate, pentru că adultul îi știe originea, devine un comportament care îi va fi interzis lui Vasea, copilul.

${ }^{13}$ Sfârșitul copilăriei este și numele unui capitol din Bandiții, care va fi analizat în cele ce urmează. 
oprească sângerarea, iar lui Keșa, pentru că a acționat fără ordin, i se retează degetul mic de la mâna stângă (este lăsat să aleagă care mână să fie „însemnată” pentru această încălcare a interdicţiei), în prezența băiatului. După acest episod, Profesorul își explică acțiunile și oferă lecțiile necesare.

Vasea este imediat reperat ca neaparţinând locului când intră în „Ancora neagră”. Deși am afirmat mai sus că bandiții sunt foarte vizibili printre ceilalți indivizi, ceea ce îi și individualizează și marginalizează în același timp, acest lucru nu înseamnă că ei se arată prea des în cadrul comunităţilor de indivizi normali sau că, atunci când o fac, se declară bandiți:

„De exemplu, s-ar putea să existe o tavernă care este un loc de întâlnire pentru hoți. Deși mulți dintre hoții orașului s-ar putea să fie găsiţi într-un singur loc pentru un cercetător care vrea să-i studieze, ei s-ar putea să «facă pe proștiii» când el intră în tavernă, refuzând să aibă de-a face orice cu el sau prefăcându-se ignoranți în legătură cu lucrurile de care este el interesat." ${ }^{14}$ (Becker, 1997: 169-170).

Deși Vasea nu are statutul unui cercetător, el tot rămâne un străin, un outsider, cineva care nu aparține lumii de la „Ancora neagră”. Nu prezintă niciun semn specific, care să-i atenționeze pe cei care frecventează localul că ar fi „unul de-ai lor”. Intrarea naratorului în local poate fi echivalată cu intrarea unui corp străin într-un alt corp (cel al bandiților, de data asta): sistemul imunitar va da alerta, producând o reacție în lanț, care poate presupune inclusiv un efect inflamator (nasul spart al lui Vasea și degetul retezat al lui Keșa). De altfel, faptul că un grup conotat ca fiind marginal marginalizează la rândul său nu este un fenomen nemaiîntâlnit. Din acest motiv, Vasea este primit cu neîncredere, ceea ce atrage după sine un întreg limbaj verbal, dar și corporal specifice, menite a-l intimida:

„tipul nu mă privea în ochi, mă ignora pur și simplu. Era un fel de ami spune că nu sunt bine-venit până nu-l conving că e vorba de ceva serios. Bandiții au o mulțime de astfel de tehnici de intimidare, de retorică, de coreografie, de mimică a întregului corp și, mai ales, a mâinilor." (Ernu, 2016: 64).

Singurul lucru prin care naratorul poate convinge pe un bandit de intenţiile sale, ca să primească informația dorită, este prin retorică (verbală și corporală): „Știam că nu trebuie să fiu defensiv [...]. Știam că trebuie să-1 privesc în ochi și să fiu convingător [...]. Lipsa fricii pune la îndoială și taie

\footnotetext{
14 În original: "For example, there may be a tavern that is a hangout for thieves. While many of the thieves of the city will thus be available in one place to a researcher who wants to study them, they may "dummy up" when he enters the tavern, refusing to have anything to do with him or feigning ignorance of the things he is interested in.".
} 
elanul oricărui golan și, mai ales, al oricărei autorități.” (Ernu, 2016: 65). În traducere, ceea ce gândește, ceea ce vorbește și ceea ce face Vasile trebuie să se suprapună exact pentru ca el fie crezut, când nu are nicio altă formă de legitimitate din punct de vedere identitar. Acest lucru nu se întâmplă. Pe deasupra, încearcă să intimideze un bandit, apelând la autoritatea Profesorul, pe lângă faptul că îl etichetează ca „fraier” pe Keșa. Lecția finală a Profesorului pentru băiat, după acest incident, care devine un punct de cotitură din punct de vedere identitar, este următoarea:

„Și o să-ți mai spun un lucru pe care trebuie să-l ții minte toată viața: niciodată, dar niciodată să nu te dai drept ceea ce nu ești! [...] Iar pentru asta e nevoie să știi cine ești și ce poți și să-ți asumi, căci nimeni nu va răspunde pentru tine şi faptele tale. [...] Keşa pentru asta te-a pedepsit, pentru că ai încercat să te dai drept ceea ce nu ești și să folosești numele meu ca pretext și acoperire.” (Ernu, 2016: 71).

Ceea ce se întâmplă cu Vasea la „Ancora neagră” este o inițiere, dar nu în lumea criminalității, cât în lumea adulților mai degrabă. Din acest motiv, naratorul este tratat mai blând de Profesor decât banditul Keșa, pentru că identitatea sa nu suferă o revoluție coperniciană. Vasea nu este (și nici nu va considera asta despre el însuși vreodată) un bandit (sau, mai degrabă, nu acel bandit care și fură). Doar pentru faptul că păstrează legătura de la distanță cu lumea infracțională, după ce a fost cvasi-inițiat, nu înseamnă că face parte din grup, rămânând un „fraier” (unul protejat de Profesor) pentru bandiți. Keșa, pentru că, o dată intrat în lumea bandiților, a acceptat tot codul și cunoașterea acestuia, este pedepsit pentru transgresiunea sa:

„Pedepsele trebuie să fie marcate, căci altfel se uită. La noi, legile se scriu pe corp. Fericirea şi pedeapsa trebuie trecute în istoria noastră personală. E ca un dosar, e ca o biografie a noastră. Însă la noi totul se trece nu pe hârtie, ci direct pe piele. (s.n., I.S.) [...] Iar ceea ce i-am făcut eu lui Keșa nu e o pedeapsă, ci mai degrabă o binecuvântare și o iertare." (Ernu, 2016: 70).

„Din cauza riscurilor mult mai mari pe care le implică activitățile ilicite, se poate presupune ușor că presiunea normativă din interiorul grupului criminal este mai mare decât în cazul asociațiilor care intră, prin statut și activități, în sfera legalității.” (Țăranu, 2013: 255),

motiv pentru care pedepsele sunt lipsite de echivoc și vizibile pentru oricine, nu doar pentru grupul bandiților. Viziunea romantică asupra bandiților, pe care autorul i-o împrumută naratorului copil, este de înțeles în context: ,întotdeauna i-am privit pe acești îngeri căzuți ca pe niște ființe triste și 
demne de milă. Ei erau oamenii cei mai însingurați, care aveau nevoie de mila noastră, de mângâierea noastră.” (Ernu, 2016: 166). Viziunea, până la urmă, este cea a unui sectant care crede că lumea încă poate fi salvată prin iubire și propriul exemplu, dar adverbul ,întotdeauna" urmat de un verb la timpul trecut, perfect compus, ,am privit”, arată o discrepanță între planurile narative. Este naratorul adult cel care face afirmația? Este vorba de adultul care atribuie copilului această viziune naiv-creștin-sectantă? Este chiar a autorului, care se confundă constant cu naratorul său, ambiguitate pe care, de altfel, nici nu încearcă s-o tranșeze (fertilă pentru Vasile Ernu, cel puțin, dacă nu și pentru naratologie și storytelling), fiind un stil care 1-a făcut cunoscut?

Ceea ce ar trebui reținut de aici este faptul că, până în acest punct, Vasea rămâne un exponent al unei culturi marginale (cea a sectanților), fiindcă el nu renunță la această identitate pentru a o înlocui cu cea de bandit. Deși vârsta destul de fragedă poate reprezenta un teren fertil pentru explorarea diferitelor identități virtuale din care (aproape) adolescentul ar putea alege, cea de infractor nu este nicicând actualizată, oricât de multă simpatie și milă exhibă față de acești indivizi, păstrând distanța faţă de ei, și cu atât mai mult pe măsură ce se maturizează și raportul de forțe dintre putere și bandiți se schimbă. Deocamdată, marginalitatea naratorului este atribuită în mod exterior, din trei direcții diferite: „stat, biserică majoritară, lume laică.” (Ernu, 2017), dar nu se simte complet dislocat, din moment ce are un grup de suport, cel de sectanți, care normalizează comportamentul său.

\section{Acomodare între bandiți și autorități?}

În capitolul Pianistul sau virtuozitatea unui hoț de buzunare, naratorul relatează povestea Pianistului, un hoț de buzunare care, la o sărbătoare oficială, observă portofelul gros al unui înalt demnitar care face parte din aparatul de propagandă al orașului Odessa. Deși toți infractorii prezenți la sărbătoare conveniseră cu milițianul Jora, cel care povestește incidentul în mod direct, să nu acționeze în niciun fel, Pianistul e singurul care nu respectă această înțelegere. Ia banii din portofel, dar uită să închidă nasturele la sacou când îl pune la $\operatorname{loc}^{15}$. Dându-și seama de eroare, revine să îndrepte greșeala. Ceea ce-1 expune nu este faptul că se întoarce la locul crimei, cât faptul că este văzut de mai tânăra soție a nomenclaturistului, care, evident, avea aceleași interese pecuniare ca Pianistul. Acest episod devine cu atât mai relevant și deconcertant dacă este corelat cu următoarea afirmație, care aparține tot milițianului Jora:

„Fiecare ştia unde se termină puterea lui Jora Milițianul şi unde începe puterea lui Graci, a lui Froim, a Profesorului sau a Pianistului. Totul e

\footnotetext{
15 Pianistul are un întreg ritual pe care îl pune în aplicare atunci când fură, iar închiderea nasturelui face parte din acest repertoriu personal.
} 
să fie fără kipeș, fără scandal. [...] Ei își plătesc dările, noi închidem ochii și trăiește, frate, cât poți!” (Ernu, 2016: 97).

Deși în mare parte din volum Vasile Ernu le acordă circumstanțe atenuante bandiților, ba chiar pare că-i transformă în eroi, prin acest capitol demonstrează că este conștient că dinamicile se pot schimba, lăsând să se înțeleagă că, de fapt, s-au și schimbat în postcomunism, dar primele semne de schimbare apar din perioada comunistă. Deși naratorul insistă o bună parte din volum asupra legilor și codului de onoare al bandiților ${ }^{16}$ - pentru că doar astfel poate fi reglementată o ,meserie” cu riscuri atât de mari ca infracționalitatea, dar și oamenii care compun această categorie socioprofesională - cu trecerea timpului, aceste legi se dovedesc aproape inutile, mai ales după dispariția comunismului, când se poate fura la adăpostul legilor. Deși există un precedent al „conviețuirii” bandiților cu puterea în timpul celui de-al Doilea Război Mondial, când primii au luptat în război (punctul 6 din decalog, citat în ultima notă de subsol, este încălcat flagrant în acest caz), Vasile Ernu, într-un interviu, situează începutul acestei mutaţii în anii '60:

„În perioada brejnevistă mie mi se pare că are loc o mutație importantă: mecanisme de acomodare cu puterea (s.n., I.S.). Burghezia de partid și clasa de mijloc birocratică și nu doar vrea bunăstare și consum şi apelează la acești bandiți din cauza penuriei de mărfuri, iar bandiții înțeleg că se poate fura/munci mult mai eficient cu ajutorul structurilor de partid și stat. Astfel se nasc rețele destul de sofisticate și eficiente.” (Ernu, 2017).

Ținând cont de faptul că fundamentul „meseriei” de hoț este riscul maxim pentru profit maxim, este ușor de înțeles de ce hoții ajung să colaboreze cu autoritățile: se pot organiza mult mai ușor rețele locale de putere, care să dețină monopolul asupra resurselor. Pe de altă parte, devine clar și faptul că, după un timp, din cauza corupției sistemice a regimului comunist, acesta se dovedește ineficient în a redistribui bunuri spre a fi consumate. Doar pentru faptul că unii bandiți preferă acomodarea pentru a putea fura mai bine și eficient sau pentru a putea avea mai multă putere, acest lucru nu înseamnă că se aplică tuturor celor din grup. Pentru un timp, etica internă a acestuia, stabilită de elita lumii infracționale, este preponderent respectată, funcționând ca un cod de onoare, aplicabil doar lor. Astfel,

16 „2. Să nu muncești niciodată pentru cineva și, mai ales, pentru stat. [...] 5. Să nu ai propiska (reședință oficială) sau, mai bine zis, să nu ai acte oficiale (buletin, pașaport) ori să fii înregistrat la autorităţile statului. 6. Să nu faci politică și activităţi politice și să nu aparţii nici unei grupări politice. 7. Să nu recunoști nicio vină în fața autorităților statului și să nu depui mărturii sau să colaborezi cu structurile de putere ale statului." (Ernu, 2016: 204) 
concesia făcută de milițianul Jora bandiților la sărbătoarea oficială devine o recunoaștere a faptului că fiecare este doar o altă rotiță în sistem.

\section{Fostul sectant devine bandit?}

Deși V. Ernu recunoaște în cel puțin un interviu că nu și-a propus ca prin Bandiții să cartografieze întregul parcurs al mafiei din zona Bugeacului, pe care acesta o cunoaște mai bine (asta și pentru că îl interesează aceste grupuri atât timp cât sunt marginale, cât nu fac legea), în capitolul „Întâlnirea cu un bandit devenit oligarh", naratorul său este pus în ipostaza de a interacționa cu un bandit intrat în legalitate, această oportunitate fiind facilitată de Profesorul. Sub pretextul acesta, Vasile Ernu înscenează, prin intermediul naratorului său, o discuție între acesta din urmă și oligarh, în care naratorul se opune din principiu discursului profesat de oligarh ${ }^{17}$. Vasile este invitat să fie sincer cu fostul bandit, iar în urma opiniei sale, îl complimentează: „Ai fi fost un bandit bun. Păcat că moșul tău te-a lăsat să te prostești cu școala.” (s.n., I.S.) (Ernu, 2016: 335). Această afirmație, într-un mod foarte cinic, devine un compliment la adresa naratorului, chiar dacă acesta nu apreciază neapărat gestul. Fostul bandit, devenit oligarh, care acum nu mai fură și pentru redistribuție (prin intermediul rețelelor locale) în rândul populației majoritare, ci doar pentru el și rețeaua sa clientelară, îl gratulează pe Vasile pentru sinceritate și faptul că nu pretinde că ar fi altceva decât este în realitate (pentru că, în linii mari, asta ar însemna faptul că ar fi fost un bun bandit, dacă ar fi renunțat la principii, la toate sau doar la unele). Este cu atât mai cinic cu cât, teoretic, inclusiv acest fost bandit, pot presupune că a respectat aceleași reguli impuse prin legea hoților, mai ales cea de a nu colabora cu puterea. Pe de altă parte, această lege contravine cu fundamentul „meseriei” de bandit: riscul maxim atrage după sine profitul maxim. Dacă impulsul este să crezi că riscul scade (sau este anulat complet) o dată cu intrarea în legalitate a furtului (atât timp cât te afli pe partea corectă a baricadei), naratorul, în idealismul său romantic, de gherilă, își avertizează cititorul că nu e chiar așa:

„Voi sunteți doar niște foști bandiți. Ați uitat de unde ați plecat? Bun, vă transformați în noua burghezie și noii aristocrați, dar în acest caz

\footnotetext{
${ }^{17}$ Dacă este luată ca principalul punct de referință tradiția franceză, scopul intelectualilor de stânga este să se opună celor care se află la putere într-un anumit moment dat (cei care s-au revoltat în 1789 se săturaseră de puterea Bisericii Catolice și de rege; cei de la sfârşitul secolului al XIX-lea care l-au susţinut pe Alfred Dreyfus protestau împotriva corupției și antisemitismului sistemului). Așa că faptul că naratorul se opune cuiva care în regimul comunist se opunea puterii (cel puțin, o parte a lumii infracționale), dar în noile condiții, a ajuns să aibă putere de decizie, este în consonanță cu identitatea acestuia, dar și cu tradiția franceză, Vasile învățând de mic a învățat să nu se încreadă în putere, oricine ar deține-o și care nici nu a făcut, pe măsură ce s-a maturizat, compromisuri morale flagrante.
} 
noi suntem nevoiți să devenim fie revoluționari, fie bandiți. Așa că făți ziduri cât China, ia-ți mașină blindată, iar copiii tăi să nu iasă din casă fără o armată de bodyguarzi, căci nimeni nu le poate garanta că se vor întoarce. Și ei ce vină au? Noi vom avea grijă ca voi să nu puteți dormi de frică. Atâta lucru să știi că am învățat de la bandiți: vă e teamă de frică. Și asta nu din cauza noastră, ci a voastră, fiindcă ați pus mâna pe tot și nu vreți să împărțiți." (s.n., I.S.) (Ernu, 2016: 337).

Istoria nu se repetă, mai ales că raportarea la timp nu mai este ciclică, ci liniară; problema este că indivizii comit aproximativ aceleași greșeli în aproximativ aceleași situații. Deși vechii bandiți furau pentru mai mult profit de pe o poziție (aproape) marginală, ajutând într-o anumită măsură la redistribuirea bunurilor pe care aparatul de stat corupt o împiedica, când se inversează pozițiile, foștii bandiți abuzează în egală măsură de putere ca cei de dinainte, deveniți marginali (sau fraieri) între timp. Așa că este de așteptat, ca la un moment dat, fix din cauza orgoliilor celor ajunși în poziții de putere, aceștia să înfrunte revoluția din nou. În mod evident, există o anumită doză de idealism în ceea ce afirmă naratorul, din simplul motiv că, de fiecare dată când are loc o revoluție, marea majoritate a populației este ignorată complet când sunt luate deciziile la nivel înalt, chiar dacă se va afirma că au fost luate fix în numele lor.

Pe de altă parte, nici despre Vasile nu se poate spune că este un marginal neapărat, nici după ieșirea din grupul de sectanți. În primul rând, acesta a emigrat în România după căderea comunismului. În al doilea rând, ajuns aici, a optat, sub o formă sau alta, pentru o formă de ascensiune socială:

„Când am ajuns în România, am înțeles sau, mai degrabă, am intuit că pentru a mă proteja trebuie să vorbesc ca majoritarii și că fiecare cuvânt și gest care-mi trădează apartenența la o «specie inferioară» sau diferită îmi blochează ascensiunea. Așa m-am apucat să învăț să-mi controlez instinctele, să-mi îmblânzesc sunetele și literele pentru a scoate acele cuvinte, sunete și fraze pe care majoritarii le cer pentru a nu-mi bloca drumul spre succes sau, mai bine zis, spre a mă integra și eu în masa majoritară indistinctă." (Ernu, 2016: 131-132).

Renunțând la suportul comunității de proveniență, comportamentul naratorului se schimbă, în jurul comunității în care acesta intră. Având în vedere că există o mare disponibilitate și a sectanților spre a se adapta oricăror condiţii sociale, chiar dacă valorile personale ale naratorului sunt diferite de cele ale lumii majoritare, acest lucru nu atrage după sine o completă inadaptare socială. Mai degrabă, are loc o constantă oscilare între valorile și comportamentele pe care diversele identități le produc: 
„Dar atavismele funcționează. Și e greu ca un copil din Imperiu, crescut în kibuțuri sectante complicate și fascinat de bandiții care îl protejau, cu o limbă foarte diferită, cu obiceiuri şi stiluri foarte particulare, să poată ascunde totul. Și mai ales formatarea gândirii și a felului de a înțelege. $\mathrm{Nu}$ se poate. Sau este foarte greu. Şi atunci ele trebuie să explodeze. Prin atitudine, prin revoltă, prin gesturi şi prin limbă." (Ernu, 2016: 132).

Naratorul, în capitolul Despre bătaie, dresaj și ritual de imperechere, împarte lumea în (aparent) două categorii: băieții buni și băieții răi. Cei buni sunt preocupați de carieră, de ascensiune socială, de a aparține grupului majoritar, de a face totul ca la carte, aceștia fiind și cei mai disciplinați. Poziția socială este cea mai importantă.

„Băieții răi sunt mereu huliganii. Le place mult să încalce normele și cutumele lumii pe care noi o numim normală. Nimic din ce fac nu pare să-i ajute să aibă succes pe termen lung. [...] Sunt copiii de care părinții încearcă să te protejeze și pe care, cu siguranță, nu-i vei aduce niciodată acasă, dacă faci parte din lumea băieților buni." (Ernu, 2016. 82).

Dar mai există și o a treia categorie, iar cel mai simplu mod de a descrie și a clasifica poziția naratorului este tot prin cuvintele sale:

„Privesc viața ca și cum toate acestea nu ar exista și, oricum, nu au nici o semnificație pentru ei și de aceea nu-i ating. Se plictisesc repede, pentru că sunt prea curioși și iau totul de la capăt de fiecare dată. Sunt indiferenți la succesul conformiștilor carieriști, dar şi la puterea aproape biologică și charismatică a huliganilor. [...] Privind în urmă însă, cred că au ceva profund ratat în ei, dar totodată sunt convins că asta îi face să fie categoria cea mai adecvată pentru această lume la fel de ratată. În ce mă privește, chiar dacă am oscilat între cele două lumi [băieți buni și băieți răi - n. m. I. S.] și am trăit și gustat din amândouă, mă simt mult mai apropiat de cea de-a treia." (Ernu, 2016: 83-84).

Poate că naratorul nu este nici carierist convins, nici bandit cu acte în regulă, dar nici marginal nu este, din ce se poate citi printre rânduri. Iar următorul exemplu o dovedește: la petrecerea dată de oligarh, în cinstea intelectualilor invitați (lista fiind făcută de narator), el se prezintă „cu șapca mea de proletar fără cauză, teniși chinezești și veșnicul sacou rămas moștenire de la tata. E un sacou purtat de trei generații și țin la el. E haina mea fetiș." (Ernu, 2016: 342). Pot presupune că naratorul nu a suferit (sau suferă) prea multă marginalizare de pe urma faptului că este sectant, din punct de vedere social sau economic, din moment ce se poate prezenta în 
public îmbrăcat într-un mod specific proletarului, indiferent de context, semnalând afilierea sa de stânga, și cu atât mai mult la un eveniment cu dress code. Poate că este puțin exotic, mai ales dacă alege să vorbească cu accent basa, dar naratorul lasă să se înțeleagă că este perfect integrat social în țara de adopție, chiar dacă poate i-a luat mai mult să înțeleagă anumite lucruri.

\section{Concluzii}

În aceste condiții, cine devine marginal în fața cui? O cunoaștere și o înțelegere atât de detaliate și nuanțate asupra mecanismelor puterii îi face pe bandiți mai apropiați și integrați (prin integrare înțeleg fix această cunoaștere profundă, cât și modul în care manevrează fluxul resurselor ce vin de la centru) decât ceea ce declară ei prin intermediul lui Vasile Ernu. Într-adevăr, sunt integrați într-un mod parazitar, cum observă Robert J. Dunne (2005: 20), dar același model poate fi observat și în natură: paraziții fac parte din gazdă, sunt parte integrantă, ecosistemul este în echilibru și - sau doar - datorită paraziților. Bandiții, prin puterea lor de adaptare, dar și prin faptul că ajung să cunoască din interior atât de bine mecanismele puterii, pot deveni din marginali chiar parte a discursului dominant în postcomunism, cum și lasă să se înţeleagă Vasile Ernu. Pe de altă parte, atât timp cât își desfășoară activitatea în regimul comunist, pot fi considerați marginali prin autoatribuire (privirea, de data asta, este a bandiților, care transformă poziția lor într-un atu; în fond, își definesc în proprii termeni marginalitatea pe care și-o atribuie). Deși autorul insistă mult în interviuri asupra dimensiunii politice a marginalității, am preferat fix modelul fluid, flexibil propus de Dan Țăranu pentru că nu este dependent de un discurs anume al puterii într-un anumit moment dat pentru a stabili cine este marginal sau nu, ci ține de moduri în care fiecare alege să se prezinte în lume, indiferent care ar fi grupul de proveniență. Marginalitatea este mai curând graduală, se schimbă în funcție de privitor (sau atribuitor/cel căruia i se atribuie). Dacă mai și există o cultură marginală, cum se întâmplă atât cu naratorul, care este un sectant crescut întrun soi de kibuț, cât și cu bandiții, aparținătorii nici nu resimt faptul că nu ar aparține unui grup, putându-se integra și în alte grupuri, cu valori diferite, în funcție de valorile pe care este dispus un individ să le pună între paranteze pentru un timp sau cât sunt dispuși membrii celorlalte grupuri să-i accepte identitatea exhibată în alte grupuri (evident, asta implică și o doză de risc, pe care individul și-o asumă, în funcție de ce pierde sau câștigă în urma faptului că este egal față de sine în orice context/grup). Și, de fapt, acesta este un alt fir roșu al volumului Bandiții: a ști cine ești în orice context și ce poți face, indiferent de riscuri. 


\section{Referințe:}

Becker, H.S. (1997). Outsiders. Studies in the Sociology of Deviance. New York: The Free Press.

Borin, P. (2017). „,De la Sectă la Bandă: «În comunism cetățeanul trebuia să lupte cu despotismul Statului-partid, în capitalism trebuie să luptăm cu despotismul Capitalului»»"/ "From a Sect towards a Gang: "In Communism the Citizen Had to Fight the State-Party's Despotism, in Capitalism We Have to Fight the Capital's Despotism" [interviu cu Vasile Ernu realizat de Pavel Borin în colaborare indirectă cu Bogdan http://www.platzforma.md/arhive/37126, accesat la data de 16 martie 2021.

Coșa, B. (2020). „Capitalismul distruge creștinismul într-un hal în care comuniștii nici n-au îndrăznit să viseze"/ "Capitalism destroys Christianity in a way in which communists never dreamt it possible" [Vasile Ernu în dialog cu Bogdan Coșa], https://blog.goethe.de/dlite/archives/812-Capitalismuldistruge-cretinismul-intr-un-hal-in-care-comunitii-nici-n-au-indrznit-sviseze-Vasile-Ernu-in-dialog-cu-Bogdan-Coa.html; accesat la data de 11 martie 2021.

Dobrescu, C. (2017). „De la o lume-a-lumilor la alta: Vasile Ernu ca stalker intercultura"l/ "From a world-of-worlds to another: Vasile Ernu as an intercultural stalker". În Observator cultural, nr. 865, https://www.observatorcultural.ro/articol/de-la-o-lume-lumilor-la-altavasile-ernu-ca-stalker-intercultural/; accesat la data de 11 martie 2021.

Dunne, R.J. (2005). "Marginality. A Conceptual Extension”. In R. M. Dennis (Ed.), Marginality, Power and Social Structure: Issues in Race, Class and Gender (pp. 11-27). San Diego: Elsevier.

Ernu, V. (2016). Bandiţii/ The Bandits. Iași: Polirom.

Rapotan, N. (2020) „A scrie o carte nu e chiar un lucru romantic.”/ "To write a book is not all that romantic" [Nona Rapotan în dialog cu Vasile Ernu], http://bookhub.ro/a-scrie-o-carte-nu-e-chiar-un-lucru-romantic-nonarapotan-in-dialog-cu-vasileernu/?fbclid=IwAR39ePGWeOb ApS4GyfqPy5cX0uZgZHe33PAFkZermQbKffQ2kI0Ue4E3I, accesat la data de 16 martie 2021.

Steward, S.M. (1990). Bad Boys and Tough Tattoos. A Social History of the Tattoo with Gangs, Sailors and Street-Corner Punks 1950-1965. New York: Harrington Park Press.

Țăranu, D. (2013). Toposul marginalității în romanul românesc. Dimensiuni ale marginalității/ The Topos of Marginality in the Romanian Novel. Dimensions of Marginality. București: Editura Muzeul Literaturii Române.

Țăranu, D. (2013). Poetici ale marginalității în romanul românesc (1900-1945)/ Poetics of marginality in the Romanian novel (1900-1945). Teză de doctorat. Braşov: Universitatea Transilvania din Braşov. 